\title{
Folia Scientifica Africae Centralis
}

A NEw quarterly bulletin, published at Bukavu, Belgian Congo, by IRSAC, is designed to provide information on the current activities of the Institut pour la Recherche scientifique en Afrique Centrale. Published in French and Flemish, with summaries in English, it gives brief accounts of recent publications and work done under the headings: Sciences biologiques, Sciences humaines, and Sciences physiques. The first number, which appeared in March I 955 , includes a summary of the work done by IRSAC in the field of nutrition since I 947 with notices of publications already issued or forthcoming; a discussion of the methodology of statistical research, with an analysis of the use of sampling techniques in RuandaUrundi; a report of the work carried out at three seismological stations (Lwiro, Uvira, and Astrida).

\section{Comité Interafricain pour les Sciences Humaines}

THE member Governments of C.C.T.A. have established an Inter-African Committee for the Social Sciences, which is to be a permanent organization, working under the auspices of C.C.T.A. and designed to further co-operation and mutual consultation in the field of the social sciences in Africa. The headquarters of the committee are at Bukavu, Belgian Congo, its secretary is Doctor Jacques J. Maquet, Director of the local centre of IRSAC at Astrida. The Committee consists of six members, representing the six member governments of C.C.T.A. (Belgium, Federation of Rhodesia and Nyasaland, France, Portugal, United Kingdom, Union of South Africa).

\section{Journées Internationales Africaines de Gand, I954}

A DETAILED report of the conference held on the occasion of the Foire Internationale de Gand has been published by the Department of Agriculture, Belgian Ministry of Colonies, under the title La Collaboration des Indigènes au Developpement économique de l'Afrique. Representatives from South Africa, Italy, Portugal, Belgium, France, United Kingdom, and Netherlands took part in the Conference. M. Buisseret, Belgian Minister of Colonies, opened the proceedings with an account of the general economy of the Congo and its development; other papers dealt with economic collaboration between European and other races in the Union of South Africa, the role of Whites and Africans in the economic development of the Congo, African attitudes and economic change in Uganda, the Gezira scheme in the Anglo-Egyptian Sudan, economic development in Italian Somaliland. The report includes, besides the text of papers read, a very full account of the discussions.

\section{West African Institute of Social and Economic Research}

The Fourth Annual Conference of the West African Institute of Social and Economic Research took place at the University College of the Gold Coast, Achimota, between 28 March and 2 April 1955.

The Conference was opened by the Honourable K. A. Gbedema, Minister of Finance of the Gold Coast. Fifty-two delegates attended and 27 papers were read. Delegates to the conference came from the United Kingdom: Miss Phyllis Deane and Mr. A. Hazlewood; from France: Professor G. Leduc; from the U.S.A.: Professor W. O. Brown (Boston) and Professor R. Turner (Yale); from IFAN, Dakar: M. J. Mersadier; from IFAN, Abidjan: M. B. Holas; from IFAN, Dahomey: MM. J. Lombard, Kaeta, and C. Tardits; from Cotonou : M. A. de Cargouet (Franco-Britannic Liaison Officer); and from the Belgian Congo: 